Results Out of the 73 aPL positive patients:

- $21 \%$ were positive for a $32 \mathrm{GPI}, \mathrm{aDI}$ and $\mathrm{aDIV} / \mathrm{V}$

- $41 \%$ were positive for a $32 \mathrm{GPI}$ and aDI but negative for $\mathrm{aDIV} / \mathrm{V}$;

- $4 \%$ were positive for a 2 GPI and $\mathrm{aDIV} / \mathrm{V}$ but negative for $\mathrm{aDI}$;

- $21 \%$ were aß2GPI positive only;

- $4 \%$ were positive for aDIV/V;

- $9 \%$ were negative for antibodies against the whole molecule and the studied domains.

The prevalence of aDI was $74 \%$ among patients with thrombotic pAPS and $60 \%$ among women with obstetric manifestations. $40 \%$ of aPL asymptomatic carriers were positive for $\mathrm{aDI}$.

We observed a strong correlation between a $32 \mathrm{GPI}$ and $\mathrm{aDI}$ $(\mathrm{p}<<0.01, \mathrm{r}=0.836)$ but not aDIV/V $(\mathrm{p}=0.07, \mathrm{r}=0.216)$.

Conclusions Most of the a $32 \mathrm{GPI}$ positive sera displayed reactivity against DI, while aDIV/DV were detected in a low rate of patients. Our data suggest that DI is the immunodominant $\beta 2 \mathrm{GPI}$ epitope and that $\mathrm{aDI}$ are the main antibody population in APS patients. Future studies are warranted to better define the diagnostic and prognostic role of anti-DI in APS

\section{A5.6 ANTI-CARBAMYLATED PROTEIN ANTIBODIES ARE PRESENT IN MICE WITH COLLAGEN INDUCED ARTHRITIS}

doi:10.1136/annrheumdis-2013-203219.6

Jeroen Stoop, Bisheng Liu, Jing Shi, Diahann Jansen, Leendert Trouw, Rene Toes. Dept. of Rheumatology, Leiden University Medical Center, Leiden, The Netherlands

Objective Antibodies against citrullinated proteins (ACPA) are a characteristic of rheumatoid arthritis (RA). Carbamylation is a different type of post translational modification, where a Lysine amino acid is converted into a homocitrullin. Recently we identified antibodies binding to carbamylated proteins (anti-CarP) in a subgroup of RA patients. In ACPA negative RA patients anti-CarP antibodies associate with joint damage.

The Aim of this study was to determine whether these anti-CarP antibodies are present in animal models of arthritis.

Methods Collagen induced arthritis (CIA) was induced in DBA/1 $(\mathrm{n}=29)$ and $\mathrm{C} 57 \mathrm{Bl} / 6(\mathrm{n}=20)$ mice by immunisation with type II collagen in CFA. Arthritis severity was monitored using a clinical scoring system. Non-immunised animals $(n=9)$ served as negative controls. After disease onset serum was harvested and antibody levels were determined by ELISA. The specificity of our anti-CarP. ELISA was validated using dotblots.

Results Whereas no anti-CarP antibodies could be detected in nonimmunised DBA/1 mice, anti-CarP total Ig was present in $93 \%$ of the arthritic mice. Of those mice 39\% had IgG1 and 79\% had IgG2a anti-CarP antibodies. Antibodies to citrullinated proteins could not be detected. The levels of mouse collagen-specific IgG2a correlated with the clinical score. However, the levels of the different antiCarP isotypes did not. Around $60 \%$ of the immunised C56Bl/ 6 mice developed arthritis. Anti-CarP IgG2c could be detected in 55\% of those mice and could not be detected in the mice that did not get CIA. Anti-CarP IgG1 was detected in $28 \%$ of the arthritic mice. Interestingly, mouse collagen specific IgG2c antibodies were detected in $100 \%$ of the immunised C57Bl/ 6 mice. Dotblot analysis, using carbamylated and non-modified proteins confirmed the ELISA results regarding the specificity of the antibodies for homocitrulline containing proteins.

Conclusions Mice with CIA have antibodies to carbamylated proteins and their presence associated with disease development. All immunised mice have anti-mouse CII antibodies, indicating that the presence of anti-CarP antibodies could be a disease specific marker for arthritis in mice. Further studies will be required to determine the role of anti-CarP in the pathogenesis of arthritis.

\section{A5.7 AUTOANTIBODIES TO THE FIBRIN-DERIVED CITRULLINATED PEPTIDES $\alpha 36-50$ AND $\beta 60-74$ ARE TWO DISTINCT NON-OVERLAPPING SUBFAMILIES OF ACPA THAT TOGETHER ALMOST SUMMARISE THEIR REACTIVITY TO CITRULLINATED FIBRINOGEN AND TO CCP2 ANTIGENS}

doi:10.1136/annrheumdis-2013-203219.7

${ }^{1} \mathrm{M}$ Cornillet, ${ }^{1} \mathrm{M}$ Sebbag, ${ }^{2,3} \mathrm{E}$ Verrouil, ${ }^{4} \mathrm{~A}$ Magyar, ${ }^{2} \mathrm{~A}$ Ruyssen-Witrand, ${ }^{4} \mathrm{~F}$ Hudecz, ${ }^{2} \mathrm{~A}$ Cantagrel, ${ }^{1,3} \mathrm{G}$ Serre, ${ }^{1,3} \mathrm{~L}$ Nogueira. 'Laboratory of "Epidermis Differentiation and Rheumatoid Autoimmunity", UMR CNRS 5165, INSERM U 1056, Toulouse III University; ${ }^{2}$ Rheumatology Center, University Hospital of Toulouse; ${ }^{3}$ Laboratory of Cell Biology and Cytology, University Hospital of Toulouse; Toulouse, France; ${ }^{4}$ Research Group of Peptide Chemistry, Department of Organic Chemistry, Hungarian Academy of Sciences, Eötvös Loránd University, Budapest, Hungary

Objectives To evaluate the proportions of Rheumatoid Arthritis (RA) sera containing autoantibodies to citrullinated proteins (ACPA) reactive to $\alpha 36-50$ and/or $\beta 60-74$ two citrullinated peptides identified as bearing the immunodominant epitopes of their major target: citrullinated fibrin. To analyse the relationships of anti- $\alpha 36-50$ and anti- $\beta 60-74$ autoantibodies with autoantibodies to the whole citrullinated human fibrinogen (AhFibA) and with anti-CCP2 antibodies.

Methods 617 sera from 181 established RA and 436 non-RA rheumatic diseases were tested by ELISA for AhFibA, anti-CCP2, anti- $\alpha 36-50$, anti- $\beta 60-74$ autoantibodies, and by nephelometry for Rheumatoid Factor (RF). Diagnostic indexes, correlations and concordances between tests were analysed. Cross-reactivity between anti- $\alpha 36-50$ and anti- $\beta 60-74$ autoantibodies was analysed with peptide absorption experiments.

Results At diagnostic specificity of $95 \%$, the diagnostic sensitivity of AhFibA (83\%) was significantly higher than that of all other tests. The diagnostic sensitivity of anti- $\beta 60-74$ autoantibodies (71\%) was significantly higher than that of anti- $\alpha 36-50(51 \%)$ but similar to that of anti-CCP2 (74\%). Titres of RF, anti- $\alpha 36-50$ and anti- $\beta 60-74$ autoantibodies were weakly correlated with each other, whereas titres of anti- $\beta 60-74$ were strongly correlated with those of AhFibA (rho $=0.633$ ) and of anti-CCP2 (rho $=0.634)$. More than $90 \%$ of AhFibA-positive or anti-CCP2-positive sera recognised the $\alpha 36-50$ and/or the $\beta 60-74$ peptide. Absorption experiments showed that anti- $\alpha 36-50$ and anti- $\beta 60-74$ mainly correspond to 2 non-cross reactive subfamilies of ACPA.

Conclusions Autoantibodies to $\alpha 36-50$ and $\beta 60-74$ are two distinct non-overlapping subfamilies of ACPA that together almost summarise the ACPA reactivity to citrullinated fibrinogen and to CCP2 antigens. In established RA, anti- $\beta 60-74$ autoantibodies show diagnostic indexes similar to those of anti-CCP2.

\section{A5.8 B CELL DEPLETION THERAPY IN A COHORT OF PATIENTS WITH SEROPOSITIVE AND SERONEGATIVE RHEUMATOID ARTHRITIS}

doi:10.1136/annrheumdis-2013-203219.8

ML Velloso Feijoo, R Martínez Pérez, L Mayordomo Gonzalez, JL Marenco de la Fuente. Rheumatology Unit, Valme University Hospital, Seville, Spain

Background B cells play a crucial role in the pathogenesis of rheumatoid arthritis (RA). They are responsible for the autoantibodies formation such as rheumatoid factor (RF) and anti-cyclic citrullinated peptide antibodies (anti-CCP) and the production of cytokines, act as antigen presenting cells and regulate $\mathrm{T}$ cell functions.

Rituximab (RTX), murine monoclonal antibody which selectively targets CD20-positive B-cells, has proved to be an effective and safe therapy for active RA. Initially it was used in seropositive RA, but considering the other functions of B cells, it is logical to think that it is also useful in seronegative forms. 